\title{
大阪湾沿岸域の二酸化炭素の挙動 \\ Carbon Dioxide Dynamics in Coastal Regions of Osaka Bay
}

\author{
藤井智康 $^{1}$. 駒井幸雄 ${ }^{2} \cdot$ 藤原建紀 $^{3}$ \\ Tomoyasu FUJII, Yukio KOMAI and Tateki FUJIWARA
}

\begin{abstract}
Measurement technique of $\mathrm{CO}_{2}$ for coastal seas is developed and applied to elucidate $\mathrm{CO}_{2}$ dynamics in the coastal regions, where the photosynthetic rate is far larger than that in the open sea and the short-term change is significant. Continuous measurements of salinity, $\mathrm{pH}$ and $\mathrm{DO}$ were conducted at three stations in Osaka Bay. The values of $\mathrm{CO}_{2}$ related terms were calculated using a classical method that uses $\mathrm{pH}$ and total alkalinity. Dissolved inorganic carbon (DIC) and DO fluctuated with high correlation $\left(\mathrm{R}^{2}=0.97\right)$. This suggests that $\mathrm{CO}_{2}$ system can be measured by this method in coastal regions. $\mathrm{DO}$ and $\mathrm{pCO}_{2}\left(\mathrm{CO}_{2}\right.$ partial pressure) records in the eastern Osaka Bay, where primary production is significant, indicated prominent diurnal variations which correspond to diurnal irradiation variations. In contrast, magnitudes of $\mathrm{DO}$ and $\mathrm{pCO}_{2}$ variations were smaller in a well mixed reason in the western Osaka Bay.
\end{abstract}

\section{1.はじめに}

地球温暖化の原因とされる温室効果ガスの 1 つである 二酸化炭素 $\left(\mathrm{CO}_{2}\right)$ の動態は, 地球規模の気候変化を引 き起こすことが予測されている。また，海水中の $\mathrm{CO}_{2}$ 濃 度も近年, 増加傾向にあり, これが海洋生物にも大きな 影響を及ぼすと考えられている。海洋と陸域の境界に位 置し，われわれの生活に身近な沿岸海域は，陸域からの 炭素の受け皿になっており，また高い生産力を持つこと から，大きな $\mathrm{CO}_{2}$ 吸収があると考えられる．しかしなが ら, 外洋の $\mathrm{CO}_{2}$ 収支に関する研究は多いのに対し, 一次 生産が大きい沿岸海域に扔ける研究は少ない。最近にな って欧米でその研究が行われるようになってきたが（例 えば, Chen・Bortges, 2009), 日本の沿岸海域での研究 は不足しているのが現状である.

藤原（2010）㧍よび藤井ら（2010）は，底層の酸素消 費と $\mathrm{CO}_{2}$ 生成は連動しており, 貧酸素・無酸素水塊中に は $\mathrm{CO}_{2}$ が高濃度で蓄積されており, 海水の $\mathrm{pH}$ が低下し， 海洋の酸性化が起きていることを示した。また，風によ る吹送にともない躍層面が昇降を繰り返し，底層に形成 された貧酸素で二酸化炭素分圧 $\left(\mathrm{pCO}_{2}\right)$ の高い水塊が動 き，ときには水面まで湧昇することも観測された。これ らのことから, 貧酸素化が問題となる沿岸海域の $\mathrm{CO}_{2}$ の 吸収・放出は短期的に変動していることが推察される.

本研究では, 外海に比べて, 光合成・有機物分解速度 が大きく, 短期的変動が大きい沿岸海域において, $\mathrm{CO}_{2}$ 系の測定手法の開発と, 貧酸素水塊の発生・消滅に連動 して変動する $\mathrm{pCO}_{2}$ の変動特性の解明を行った.

1 正会員 博(理) 奈良教育大学 准教授 教育学部

2 正会員 博(学) 大阪工業大学 教授 工学部

3 正会員農博 京都大学大学院 教授 農学研究科

\section{2. 現地調査および解析}

大阪湾沿岸域の二酸化炭素の挙動を明らかにするため に，図-1に示す3測点で観測を行った.

\section{(1) 連続観測}

混合域に位置するSt.1（垂水港）では，2010年 9 月 22 日〜29日の間，海面下 $0.5 \mathrm{~m}$ に東亞 DKK社製多項目水質 計WQC-24 およびJFEアドバンテック社製水温・塩分計 ACT-HRを設置し，10分間隔で水温，塩分， $\mathrm{DO}, \mathrm{pH}$ の 連続観測を行った。強閉鎖性海域に位置するSt.2（新西 宮ヨットハーバー：以下 YHと称す）では，2010年10月 7 日〜28日㧍よび12月1日〜16日の間，St.1 と同様な連 続観測を行った。また，上記の連続観測期間中には，1 週間間隔で設置機器の掃除および点検を行うと同時に, St.1〜3に抢いて水温，塩分，DO, pHの鉛直分布を水深 $0.5 \mathrm{~m}$ 間隔で測定した.

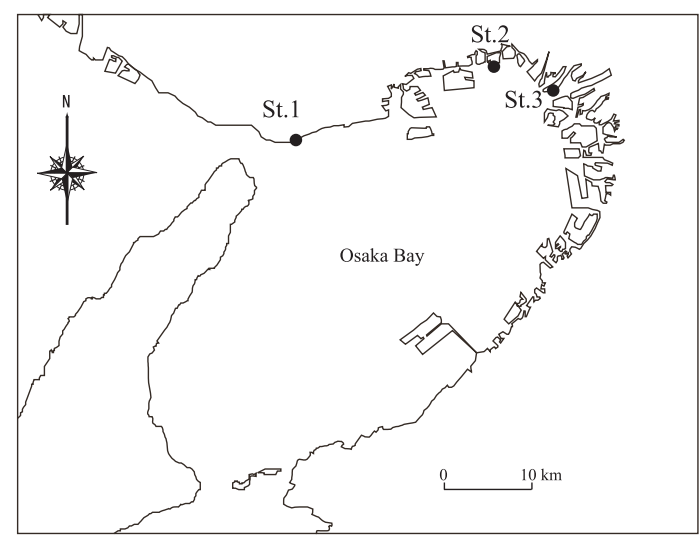

図-1 調查地点図

St.1 : 垂水港, St.2：新西宮 YH, St.3 : 尼崎港 


\section{(2) 二酸化炭素の解析}

海水中の炭酸系の各濃度を求めるためには，二酸化炭 素分圧 $\left(\mathrm{pCO}_{2}\right), \mathrm{pH}$ ，全炭酸および全アルカリ度の 4 項 目のうち，任意の 2 項目を測定すれば，計算で求めるこ とができる。本研究では，炭酸系の各項目の值を $\mathrm{pH}$ と 全アルカリ度（以下 $\mathrm{TA}$ ）から計算で求めた。計算ソフ トはCDIAC (Carbon Dioxide Information Analysis Center) が提供する $\mathrm{CO}_{2} \mathrm{SYS}$ (Lewis・Wallace，1998）を用いた. 全アルカリ度については，田口ら（2009）による大阪湾 での全アルカリ度と塩分との関係式を用いて算出した。 表面海水の $\mathrm{pCO}_{2}$ と大気の $\mathrm{pCO}_{2}(380 \mu \mathrm{atm})$ の差 $\left(\Delta \mathrm{pCO}_{2}\right)$ が正のとき $\mathrm{CO}_{2}$ の海水から大気への放出, 負のとき吸収 とした.

また, 今回調査した海域と沖合海域の比較を行うため, 第五管区海上保安本部海洋情報部の大阪湾環境保全調査 の塩分・水温・ $\mathrm{pH}$ デー夕を提供して頂き解析に用いた.

\section{3. 調査結果}

(1) 季節変化

図-2に示すように，強閉鎖性海域のSt.2では10月中旬
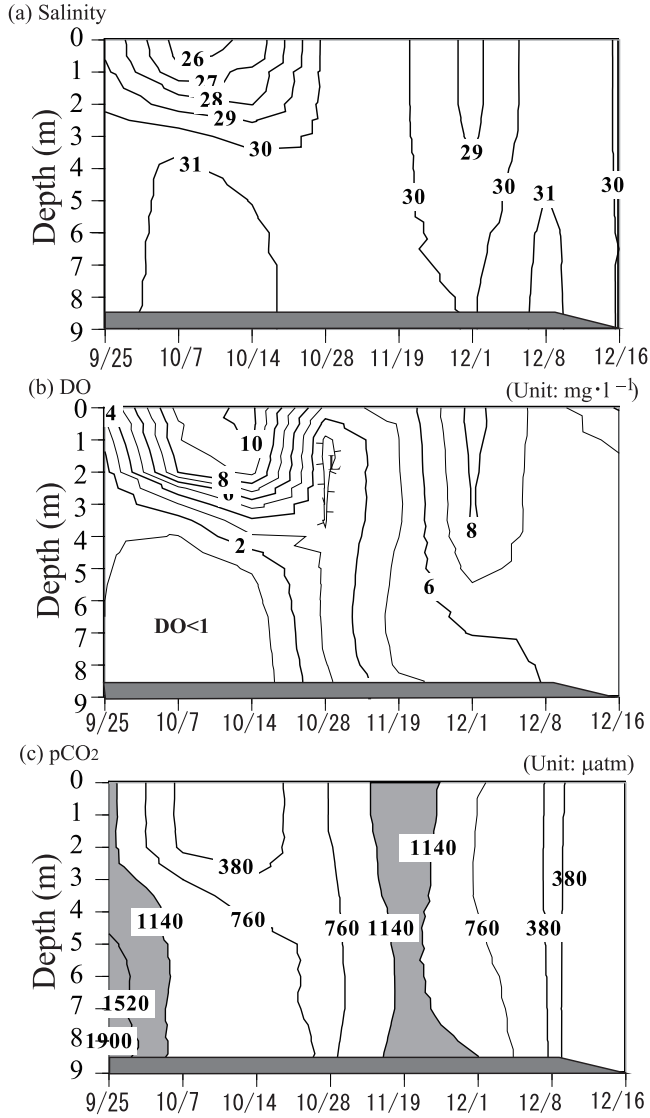

図-2 St.2（YH）における塩分, DO, $\mathrm{pCO}_{2}$ の季節変化
まで, 水深 $2 \sim 3 \mathrm{~m}$ 付近に塩分躍層が形成されており，そ れ以深では DOが $3 \mathrm{mg} \cdot 1^{-1}$ 以下の貧酸素水塊が形成され ていた. 水深 $4 \mathrm{~m}$ 以深では, DOが $1 \mathrm{mg} \cdot \mathrm{l}^{-1}$ 以下となって いた。また，海面下 $0.5 \mathrm{~m} の \mathrm{DO}$ の連続観測から，10月 22 日以降にDOが $4.0 \mathrm{mg} \cdot 1^{-1}$ 以下となり，10月 28 日までに 徐々に低下し, DOが3.0mg ・ $1^{-1}$ 以下となっていた。この 期間，DOおよび pHは低下し続けていた（図-5参照）。 $\mathrm{pCO}_{2}$ は，躍層以深では，1,140 $\mu \mathrm{atm}$ 以上（大気平衡分圧 $380 \mu \mathrm{atm}$ の 3 倍以上）と高くなっていた，その後，10月 下旬から 11 月中旬にかけての塩分躍層の消滅にともな い, 高 $\mathrm{pCO}_{2}$ 水が表層付近にまで達していた.

表層海水の $\mathrm{pCO}_{2}$ は，成層安定期では大気平衡分圧に 近い值を示すのに対し，10月下旬から11月中旬にかけて の成層消滅期には高くなり, 大気への $\mathrm{CO}_{2}$ 放出になって いた.

秋季の成層崩壊と卓越風向の変化により, 底層に蓄積 された高 $\mathrm{pCO}_{2}$ 水が水面まで湧昇し, $\mathrm{CO}_{2}$ の大気への放出 となっていると考えられる。また，図-3に示すように， 大阪湾奥部に位置するSt.3では, St.2 と同様な変動がみ られた。
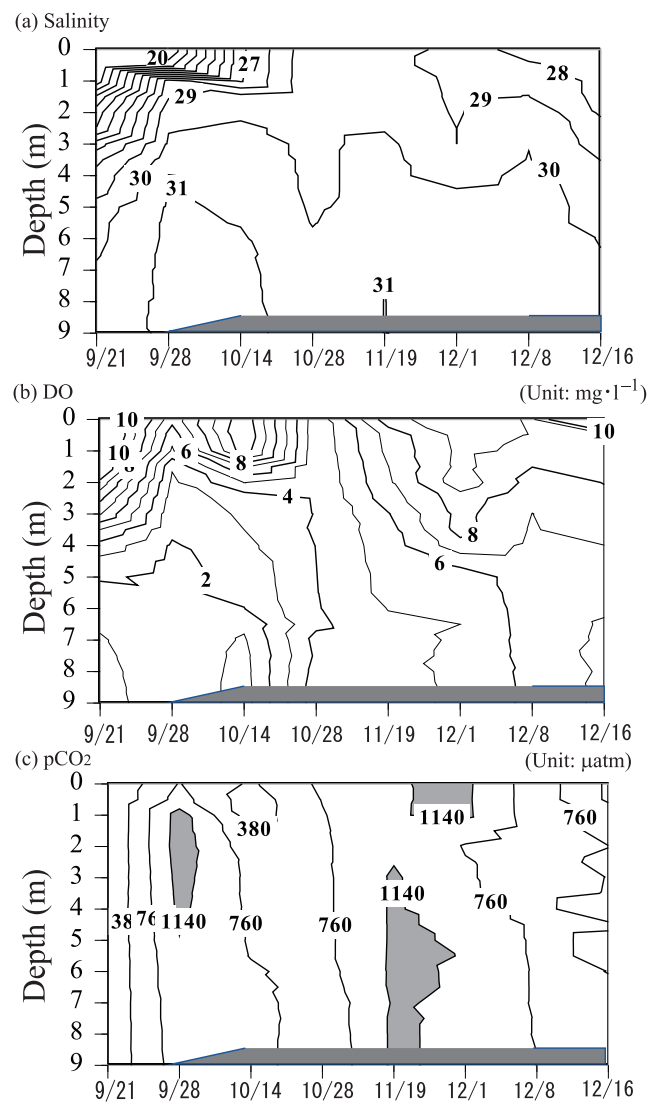

図-3 St.3（尼崎港）における塩分, DO, $\mathrm{pCO}_{2}$ の季節変化 


\section{(2) $\mathrm{DO} \cdot \mathrm{pH} \cdot \mathrm{pCO}_{2}$ の短期変動}

図-4に示すように, 混合域のSt.1のDOの変動は, 飽和 溶存酸素濃度以下の $5 \sim 6 \mathrm{mg} \cdot 1^{-1}$ の間で変動し, 日中に 高く, 夜間に低くなる日周期変動がみられた。 $\mathrm{pH}$ の変動 は8.0〜8.1であり, 表面海水の $\mathrm{pCO}_{2}$ はほぼ大気平衡状態 であった。また，図-5に示す強開鎖性海域のSt.2のDOの 変動は, 日周期変動が顕著にみられた。夜間の DOの低 下にともない, $\mathrm{pH}$ が低下し, $\mathrm{pCO}_{2}$ は上昇していた。 DO が過飽和となっている10月20日頃までは, $\mathrm{pH}$ は8.4〜 8.8 の変動であり, $\mathrm{pCO}_{2}$ は $100 \mu \mathrm{atm}$ 程度と低く, $\mathrm{CO}_{2}$ の吸 収となっていた。一方で, 海面付近で $3.0 \mathrm{mg} \cdot 1^{-1}$ 以下の 唄酸素水が確認された 10 月 24 日以降は, $\mathrm{pH}$ ガ 8.0 以下に
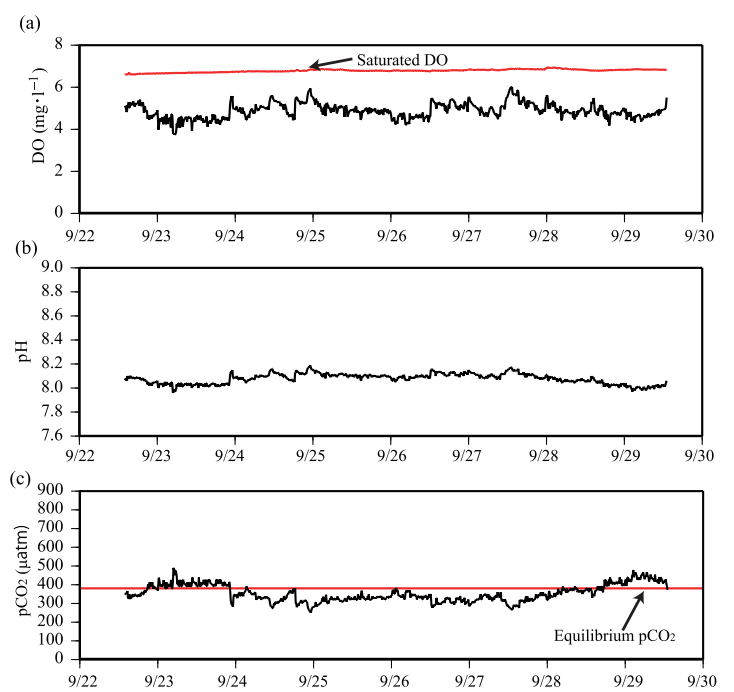

図-4 St.1 (垂水港)の海面下 $0.5 \mathrm{~m}$ における DO, $\mathrm{pH}, \mathrm{pCO}_{2}$ の 変動（2010年9月22日～29日）

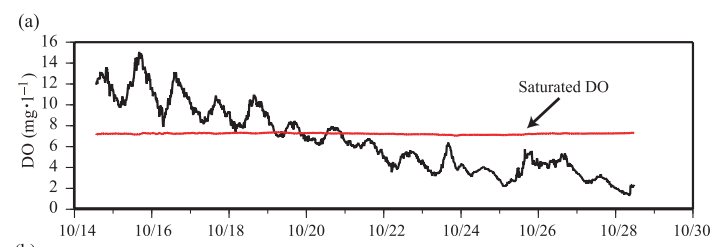

(b)
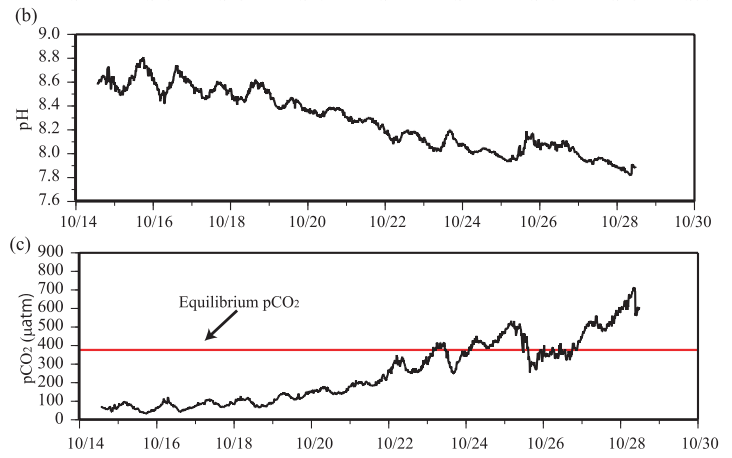

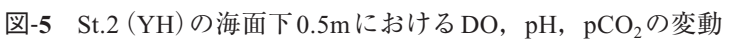
(2010年10月 14 日〜 28 日)
低下し, $\mathrm{pCO}_{2}$ も徐々に $380 \mu \mathrm{atm}$ 以上に上昇し, 10 月 28 日には $700 \mu \mathrm{atm}$ に達していた.

日射量の日周期変動にともなう光合成強度の変動によ り， $\mathrm{DO}$ および $\mathrm{pCO}_{2}$ は日周期変動をしていた. $\Delta \mathrm{pCO}_{2}$ の 日周期変動幅 /平均值は, DOの日周期変動幅 $(\Delta \mathrm{DO})$ のそれの $1 / 4$ と小さい.

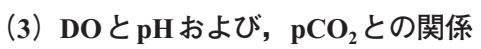

図-6に示すように, St.2の表層では, DOの低下ととも に $\mathrm{pH}$ が低下し， $\mathrm{pCO}_{2}$ が上昇していた。また, $\mathrm{pCO}_{2}$ の上

(a)

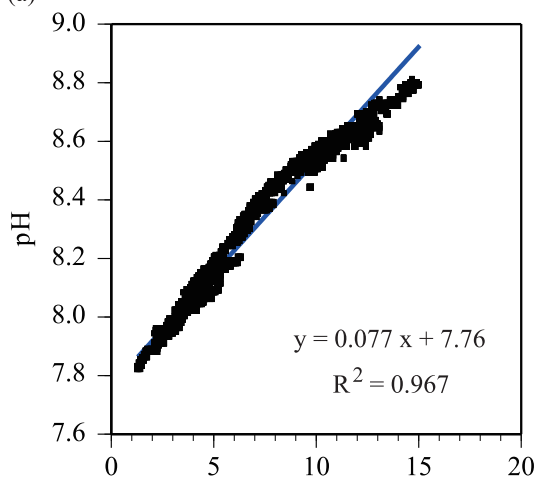

(b) $\mathrm{DO}\left(\mathrm{mg} \cdot 1^{-1}\right)$

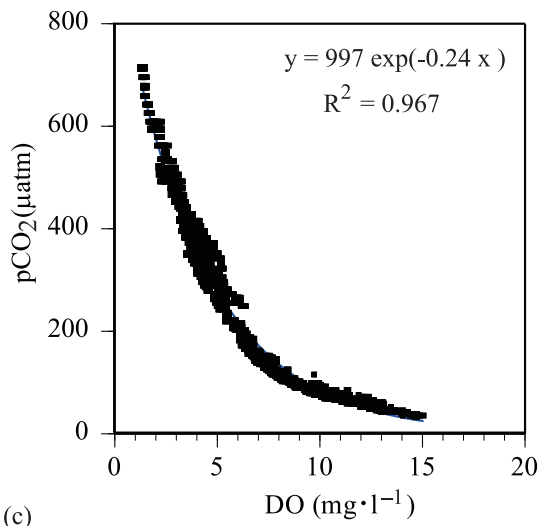

(c)

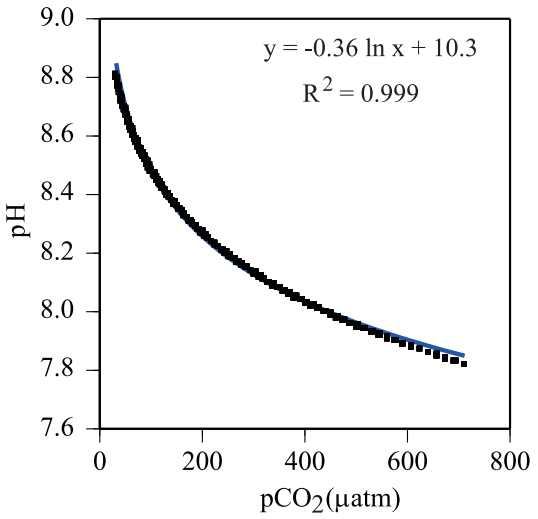

図-6 St.2 (YH)における (a) DO と pH, (b) DO と $\mathrm{pCO}_{2}$ および $(\mathrm{c}) \mathrm{pCO}_{2}$ と $\mathrm{pH}$ との関係 （2010年10月 14 日〜 28 日） 
昇にともない, $\mathrm{pH}$ が低下していた。つまり，表層の貧酸 素水塊中に蓄積された高 $\mathrm{pCO}_{2}$ が湧昇し, 表面の海水が 低pHになっていた。

\section{（4）大阪湾東部の表層海水の $\mathrm{pCO}_{2}$ の季節変化}

図-7に示すように，第五管区海上保安本部海洋情報部 が每月実施している大阪湾環境保全調査デー夕の表層 （海面下 $0.5 \mathrm{~m} ） の \mathrm{pH}$ と塩分デー夕を用いて，2010年 5 月 〜 2011 年 4 月の大阪湾東部の測点 $\mathrm{A}$ と $\mathrm{B}$ の $\mathrm{pCO}_{2}$ を算出 し，その変化についてまとめた。両測点とも，非成層期 および安定成層期を通じて $\mathrm{pCO}_{2}$ は $380 \mu$ atm 以下であり, $\mathrm{CO}_{2}$ の吸収となっていた。また，両地点間に明暸な違い はみられなかった。

\section{4. 考察}

\section{（1）大阪湾沿岸部の二酸化炭素の吸収と放出}

我々の観測および第五管区海上保安本部海洋情報部の 定期観測結果から, 図-8に示すように, 大阪湾沿岸部で は安定成層期には，表層では光合成が盛んに行われ，一 次生産量が高く, 表面では $\mathrm{CO}_{2}$ の吸収となっているが, 底層では有機物の呼吸分解過程で酸素が消費され, 生成 された $\mathrm{CO}_{2}$ が高濃度に蓄積される．秋季から冬季の成層 消滅期には, 卓越風向が北北東風に変化し, 底層水の沿 岸湧昇が生じやすい季節であること，および防波堤を通 じての港外の水が進入するこが知られており（藤井ら， 2010），これらの影響によって底層に蓄積された高 $\mathrm{pCO}_{2}$ 水が表面にまで達し, 大気への $\mathrm{CO}_{2}$ の放出となると推察 される。

\section{（2）二酸化炭素の短期変動特性}

海洋に扔ける二酸化炭素と溶存酸素濃度は, 海水の流 動, 水温変化および光合成や呼吸などの生物過程などに よって変動するとともに，海面フラックスによって変動

(a)
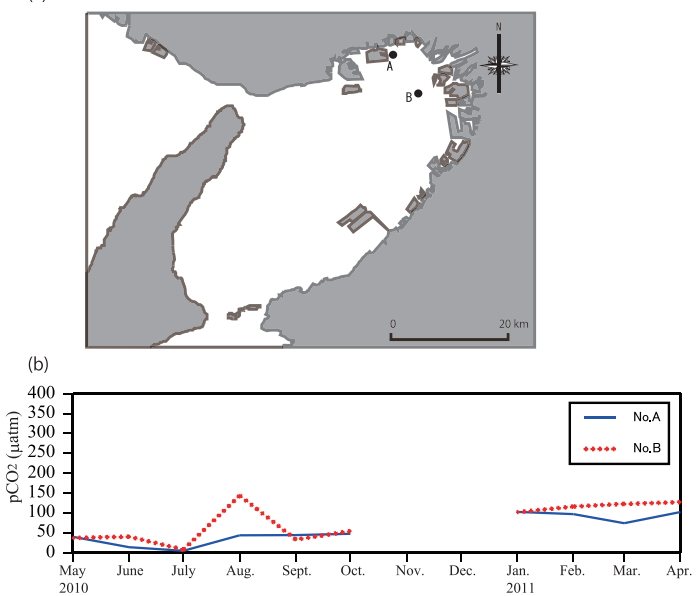

図-7 大阪湾東部の測点位置（a）および表層海水の $\mathrm{pCO}_{2}$ の 季節変化（b）（2010年5月～2011年 4 月）
する. 海水中の $\mathrm{CO}_{2}$ と大気の $\mathrm{CO}_{2}$ との交換時間は, $\mathrm{O}_{2}$ の 交換時間の 20 倍長いことが知られている (Zeebe・WolfGladrow，2005)。今回の連続観測では, 日射量の日周期 変動にともなう光合成強度の変動により, DO および $\mathrm{pCO}_{2}$ は日周期変動をしていた.

図-9に溶存無機態炭素（DIC）とDOの時系列変化を示 す. $\mathrm{pH}$ ，全アルカリ度より計算で求めた DIC はDO と高 い相関（ $\mathrm{R}^{2}=0.97 ）$ を持って変動していた。このように, 一次生産量の大きな沿岸海域では, DIC とDOが連動し て変動しており, 本報で示した方法で $\mathrm{CO}_{2}$ 系の短期的な 変動が測定できることを示唆している.

\section{（3）沿岸海洋の酸性化過程}

海洋は $\mathrm{CO}_{2}$ の主要な吸収域とされており, 地球温暖化 による大気中の $\mathrm{CO}_{2}$ の増加にともない, 海水表層の $\mathrm{pCO}_{2}$ が増加し, 海水の $\mathrm{pH}$ が低下し, 酸性化（海洋酸性化） が生ずるとされている (Doneyら，2009）。沿岸海域にお いては, 河川からの有機物や栄養塩の流入があり, 一次 生産が盛んな海域である。このような海域では，上層で は光合成により $\mathrm{CO}_{2}$ は，有機物（植物プランクトン）に 変換される。死滅した植物プランクトンは，デトリタス

(a) Stratification

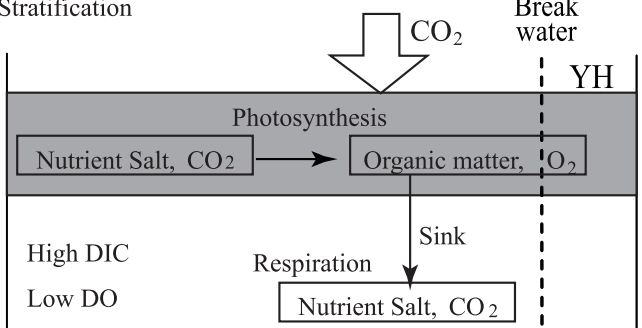

(b) Northerly wind induces the upwelling

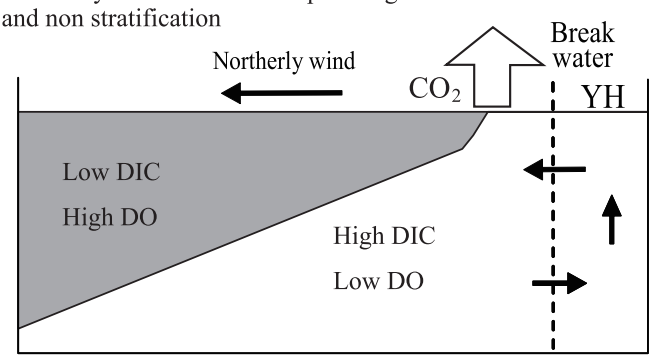

図-8 大阪湾沿岸部の二酸化炭素の吸収と放出

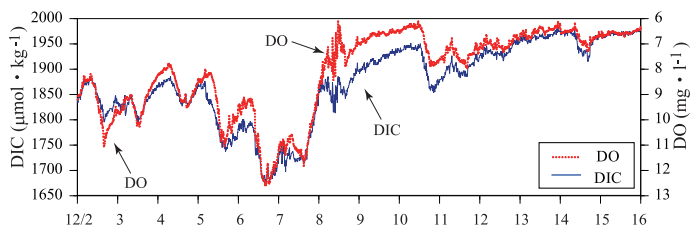

図-9 St.2（YH）におけるDIC と DOの変動 (2010年12月 2 日〜 16 日) 
となって下層に沈降する。下層の有機物は, 呼吸により 分解され無機態の窒素・リン・炭素 $($ DIN ・ DIP ・ DIC) になる.

この有機物分解により底層水中の $\mathrm{O}_{2}$ は消費され，貧酸 素化が起きるとともに, $\mathrm{CO}_{2}$ が生成され貧酸素水塊中に 蓄積される。この $\mathrm{CO}_{2}$ の生成により，底層では $\mathrm{pH}$ の低下 （海水の酸性化）が生じる。また，ある時期には，強い 陸風（岸から沖方向への風）が吹いた場合には，風の吹 送による底層水の沿岸湧昇により表面付近でも $\mathrm{pH} 8.0$ 以 下の低 $\mathrm{pH}$ となり，全層にわたって酸性化が生じる.

（4）測定誤差と $\mathrm{pH}$ スケール

海水中の炭酸系の各濃度を求めるためには, $\mathrm{pCO}_{2}$, DIC, $\mathrm{pH}$ ，全アルカリ度の4項目のうち，任意の2項目を 測定すれば他の 2 項目は計算で求めることができる (Zeebe · Wolf-Gladrow, 2005 ; Millero，2006)。本報で は全アルカリ度と $\mathrm{pH}$ から求める方法を用いた。

全アルカリ度の測定誤差は，測定值の $2 \%$ 以下と見積 もられており，各炭酸系項目の大きさは全アルカリ度に 比例するので，各炭酸系項目にも $2 \%$ の誤差があるもの とみられる（田口ら，2009）。

pHには，使用する試水のイオン強度に応じて，いくつ かのpHスケールがある（Zeebe・Wolf-Gladrow，2005； Millero，2006)。本報で用いたのはJIS-K-0101に基づく方 法であり, イオン強度 0.1 程度の淡水用の $\mathrm{pH}$ 標準液で校 正するものである $\left(\mathrm{pH}_{\mathrm{NBS}}\right)$ ，一方，海水のイオン強度は 0.7 程度と大きく, また炭酸やホウ酸の各解離常数は海水 用の $\mathrm{pH}$ スケール $\left(\mathrm{pH}_{\mathrm{total}}\right)$ で求められている（Royら， 1993).

著者らは， $\mathrm{pH}_{\mathrm{NBS}}$ と $\mathrm{pH}_{\mathrm{total}}$ の違いを補正するため，観測 時の海水をエアレーションし, $\mathrm{pCO}_{2}$ の大気平衡状態 $\left(\Delta \mathrm{pCO}_{2}=0\right)$ を作り，この状態の $\mathrm{pH}$ を測ることによっ て $\mathrm{pH}$ スケールの補正を行っている.

本報の観測は，エアレーションによる補正を行いだす 前の観測であるが，経験則に基づく $\mathrm{pH}$ スケールの補正 を行っており，DICには $2 \%$ 程度の系統誤差があるもの と推定される。一方， $\Delta \mathrm{pCO}_{2}$ の系統誤差は大きく，海面 の值で土 $70 \mu \mathrm{atm}$ 程度の誤差があるもとの推定される. しかしながら，本報の $\Delta \mathrm{pCO}_{2}$ についての定性的な記述 $\left(\mathrm{CO}_{2}\right.$ の吸収・放出, 貧酸素水塊中の高 $\left.\mathrm{pCO}_{2}\right)$ は変わら ない.

\section{5. 結論}

大阪湾沿岸部では，成層期の底層では有機物の呼吸分 解で水中の $\mathrm{O}_{2}$ が消費され，貧酸素水塊が形成されると同 時に, $\mathrm{CO}_{2}$ が蓄積されていた。秋季から冬季の成層消滅
期には, 底層の高 $\mathrm{CO}_{2}$ 水が表面まで達し, 大気への $\mathrm{CO}_{2}$ 放出が起きていた。

沿岸海域では $\mathrm{pCO}_{2}$ の時間変動が大きい（図-5）。また 鉛直的な変化も大きく(図-2), 北太平洋で水深 0 ～ $1,000 \mathrm{~m}$ (DO極小層) の間で起きていることが，水深 0 $10 \mathrm{~m}$ の間で起きている。このため沿岸海域では，炭酸系 の時間的・空間的な連続測定が久かせない，炭酸系 4 項 目のうち，係留系による連続測定やCTDによる鉛直測定 ができるのは，pHと塩分（これから全アルカリ度が算定 できる）だけであり，沿岸海域での炭酸系の測定では $\mathrm{pH}$ と全アルカリ度の組合せが適していると考えられる。

現在の $\mathrm{pCO}_{2}$ やDICの高精度直接測定に比べ, $\mathrm{pH}$ 電極 による $\mathrm{pH}$ 測定は精度が劣るものの，変動幅の大きな沿 岸海域では，本報の方法でもかなりの相対精度で炭酸系 の各項目の值を求めることができる.

今後，エアレーション海水により $\mathrm{pH}$ 值を補正する方 法により，より高精度化を図ると共に，日本各地の沿岸 海域で $\mathrm{CO}_{2}$ 系の調査を進めていきたい.

謝辞 : 本研究は大阪湾広域臨海環境整備センターの平成 22 年度「大阪湾圈域における海域環境の再生・創造に係 る研究の助成事業」により行われた，記して謝意を表す。

\section{参 考 文 献}

田口二三生 - 藤原建紀 - 山田佳昭 - 藤田弘一 - 杉山雅人 (2009)：沿岸海域のアルカリ度, 沿岸海洋研究, $47, \mathrm{pp}$ 71-75.

藤井智康・駒井幸雄・藤原建紀・横井貴範（2010）：港湾等の 強閉鎖性海域の貧酸素水塊の発生機構と動態，土木学会 論文集 B2（海岸工学），66，pp. 1046-1050.

藤原建紀 (2010)：内湾の貧酸素化と青潮，沿岸海洋研究，48, pp. 3-15.

Chen C.-T. A. and A.V. Bortges (2009) : Reconciling opposing views on carbon cycling in the coastal ocean: Continental shelves as sinks and near-shore ecosystems as sources of atmospheric $\mathrm{CO}_{2}$, Deep-Sea Research II, 56, pp. 578-590.

Doney, S.C., V. J. Fabry, R. A. Feely, and J. A. Kleypas (2009) : Ocean acidification: The other $\mathrm{CO}_{2}$ problem. Annual Review of Marine Science, 1, pp.169-92.

Lewis, E. and D.W.R. Wallace (1998) : Program developed for $\mathrm{CO}_{2}$ system calculations. ORNL/CDIAC-105, Carbon Dioxide Information Analysis Center, pp. 1-21.

Millero, F. J. (2006) : Chemical Oceanography. 3rd ed., CRC Press, Florida. 496 pp.

Roy, R. N., L. N. Roy, K. M. Vogel, C. Porter-Moore, T. Person, C. E. Good, F. J. Millero, and D. M. Campbell (1993) : The dissociation constants of carbonic acid in seawater at salinity 5 to 45 and temperature 0 to $45^{\circ} \mathrm{C}$. Marine Chemistry, 44, pp. 249-267.

Zeebe, R. E. and D. Wolf-Gladrow (2005) : $\mathrm{CO}_{2}$ in seawater: equilibrium, kinetics, isotopes. 3rd impression, Elsevier, Amsterdam, 346 pp. 